\title{
Dimethyl Carbonate as a Methylating Agent. The Selective Mono-C-methylation of Alkyl Aryl Sulfones
}

Andrea Bomben, Maurizio Selva* and Pietro Tundo*

Dipartimento di Scienze Ambientali del'Università di Venezia, Calle Larga S. Marta 2137, 30123, Venezia, Italy

At $180-210{ }^{\circ} \mathrm{C}$, $\alpha$-methylene sulfones (both benzyl aryl and alkyl aryl sulfones, $\mathrm{RCH}_{2} \mathrm{SO}_{2} \mathrm{AR}$ : $\mathrm{R}=\mathrm{Ph}, p-\mathrm{ClC}_{6} \mathrm{H}_{4}, \mathrm{Ar}=\mathrm{Ph}$, $p-\mathrm{ClC}_{6} \mathrm{H}_{4}, p-\mathrm{MeC}_{6} \mathrm{H}_{4}$, and $\left.\mathrm{R}=\mathrm{Me}, \mathrm{Ar}=\mathrm{Ph}, p-\mathrm{ClC}_{6} \mathrm{H}_{4}, p-\mathrm{MeC}_{6} \mathrm{H}_{4}\right)$ react with dimethyl carbonate to yield the corresponding mono-C-methyl derivatives $\left[\mathrm{RCH}\left(\mathrm{CH}_{3}\right) \mathrm{SO}_{2} \mathrm{Ar}\right]$ in a selectivity $>99 \%$, at conversions of $76-99 \%$ (isolated yields: 97-92\%).

$\alpha$-Sulfonyl carbanions, e.g. 1, may react with a number of different electrophiles yielding, for example, condensation with esters, aldehydes and isocyanates, though their most widely used reaction is by far nucleophilic displacement with alkyl halides [eqn. (1)]

$$
\begin{aligned}
& \mathrm{RCH}_{2} \mathrm{SO}_{2} \mathrm{Ar} \underset{\text { Base }\left(-78 \text { to }-33^{\circ} \mathrm{C}\right)}{\mathrm{R}} \mathrm{RCH}\left(\mathrm{R}^{\prime \prime}\right) \mathrm{SO}_{2} \mathrm{Ar} \\
& \mathrm{R}=\text { aryl, alkyl; base }=\mathrm{BuLi} ; \mathrm{MNH}_{2}(\mathrm{M}=\mathrm{Li}, \mathrm{Na}, \mathrm{K})
\end{aligned}
$$

However, the generation of carbanions 1 necessitates very strong bases. ${ }^{1,3-5}$ Only in the case of triflones $\left(\mathrm{RCH}_{2} \mathrm{SO}_{2} \mathrm{CF}_{3}\right)^{7}$ may mild bases act efficiently to promote alkylations; however, triflones themselves are not always accessible. ${ }^{1}$

An alternative route for alkylation processes can be conceived with the use of dialkyl carbonates (DAlCs) as alkylating agents. In particular, dimethyl carbonate (DMC) is an excellent methylating agent which allows unprecedented high mono-C- and mono-N-methyl selectivities: derivatives of both aryl- and aryloxy-acetic acid derivatives and primary aromatic amines $\left[\mathrm{XCH}\left(\mathrm{CH}_{3}\right) \mathrm{W}: \mathrm{X}=\mathrm{Ar}\right.$ and $\mathrm{ArO}, \mathrm{W}=\mathrm{CN}$ and $\mathrm{CO}_{2} \mathrm{Me}$, and $\mathrm{ArNHCH}_{3}$, respectively] have been obtained in $90-99 \%$ selectivity at substantially quantitative conversions (up to $99 \%$ ). ${ }^{12-16,1}$

This paper reports that also sulfones bearing $\alpha$-methylene groups (benzyl aryl and alkyl aryl sulfones: $\mathrm{ArCH}_{2} \mathrm{SO}_{2} \mathrm{Ar}^{\prime}$ and $\mathrm{RCH}_{2} \mathrm{SO}_{2} \mathrm{Ar}^{\prime}$ ) can be effectively mono-C-methylated (selectivity $>99 \%$ ) by DMC, even when a mild base $\left(\mathrm{K}_{2} \mathrm{CO}_{3}\right)$ is used.

Batchwise reactions are performed in an autoclave by loading a mixture of the substrate, $\mathrm{K}_{2} \mathrm{CO}_{3}$ and $\mathrm{DMC}$ in a 1:2:130-210 molar ratio, respectively, DMC acting both as the methylating agent and the solvent.

At $180-210^{\circ} \mathrm{C}$, mono-C-methylations of benzyl aryl and alkyl aryl sulfones $\left[\mathrm{ArCH}_{2} \mathrm{SO}_{2} \mathrm{Ar}^{\prime}, \mathbf{2 a}-\mathbf{c}\right.$ and $\mathbf{2 g - h}: \mathrm{Ar}=\mathrm{Ph}$, $p-\mathrm{ClC}_{6} \mathrm{H}_{4} ; \mathrm{Ar}^{\prime}=\mathrm{Ph}, p-\mathrm{ClC}_{6} \mathrm{H}_{4}, p-\mathrm{MeC}_{6} \mathrm{H}_{4}$, and $\mathrm{RCH}_{2} \mathrm{SO}_{2} \mathrm{Ar}^{\prime}$, 2d-f: $\left.\mathrm{R}=\mathrm{Me} ; \mathrm{Ar}^{\prime}=\mathrm{Ph}, p-\mathrm{ClC}_{6} \mathrm{H}_{4}, p-\mathrm{MeC}_{6} \mathrm{H}_{4}\right)$ proceed with a selectivity $>99 \%$ (at conversions of $95-99 \%$ ), and afford good to high yields $(77-92 \%)$ of isolated products $[\mathbf{3 a}-\mathbf{h}$; eqn. (4)].

$$
\begin{gathered}
\mathrm{RCH}_{2} \mathrm{SO}_{2} \mathrm{Ar}+\mathrm{MeOCO}_{2} \mathrm{Me} \underset{180-210^{\circ} \mathrm{C}}{\stackrel{\mathrm{K}_{2} \mathrm{CO}_{3}}{\longrightarrow}} \mathrm{RCH}(\mathrm{Me}) \mathrm{SO}_{2} \mathrm{Ar} \\
+\mathrm{MeOH}+\mathrm{CO}_{2}
\end{gathered}
$$

\begin{tabular}{lllll}
\hline & $\mathrm{R}$ & $\mathrm{Ar}$ & $T /{ }^{\circ} \mathrm{C}$ & Yield $(\%)$ \\
\hline 3a & $\mathrm{Ph}$ & $\mathrm{Ph}$ & 180 & 78 \\
3b & $p-\mathrm{ClC}_{6} \mathrm{H}_{4}$ & $\mathrm{Ph}$ & 180 & 76 \\
3c & $p-\mathrm{MeC}_{6} \mathrm{H}_{4}$ & $\mathrm{Ph}$ & 180 & 92 \\
3g & $\mathrm{Ph}$ & $p-\mathrm{ClC}_{6} \mathrm{H}_{4}$ & 180 & 80 \\
3h & $p-\mathrm{ClC}_{6} \mathrm{H}_{4}$ & $p-\mathrm{ClC}_{6} \mathrm{H}_{4}$ & 180 & 81 \\
3d & $\mathrm{Ph}$ & $\mathrm{Me}$ & 200 & 85 \\
3e & $p-\mathrm{ClC}_{6} \mathrm{H}_{4}$ & $\mathrm{Me}$ & 200 & 77 \\
3f & $p-\mathrm{MeC}_{6} \mathrm{H}_{4}$ & $\mathrm{Me}$ & 210 & 76 \\
\hline
\end{tabular}

A major influence on reactivity arises from the different aryl and alkyl groups directly bound to the methylene reacting group: thus benzyl aryl sulfones $\left(\mathrm{ArCH}_{2} \mathrm{SO}_{2} \mathrm{Ar}^{\prime}\right.$ : $\mathbf{2 a}-\mathbf{c}, \mathbf{g}-$ h) are efficiently mono-methylated at $180{ }^{\circ} \mathrm{C}$ while alkyl aryl sulfones $\left(\mathrm{MeCH}_{2} \mathrm{SO}_{2} \mathrm{Ar}\right.$ : 2d-f) do not, and actually require a more elevated reaction temperature of $200-210{ }^{\circ} \mathrm{C}$ for the reaction to go to completion. Such a behaviour seems to be clearly related to the stabilization of aryl sulfonyl carbanions [ $\mathrm{ArSO}_{2} \overline{\mathrm{C}} \mathrm{HAr}$ ' formed during the reactions] induced by the resonance with the adjacent $\mathrm{Ar}^{\prime}$ group.

The methylation of the sulfones $\mathbf{2 a - h}$ follows, in all likelihood, the mechanistic pattern reported for aryl- and aryloxyacetic acid derivatives. ${ }^{14-16}$ Accordingly, the monomethyl selectivity is explicable through the occurrence of two consecutive nucleophilic displacements (Scheme 1): $(i)$ a methoxycarbonylation of the initially formed sulfonyl carbanion [ $\left.\mathrm{ArSO}_{2} \overline{\mathrm{C}} \mathrm{HR}\right]\left(B_{\mathrm{Ac}} 2\right.$ mechanism) followed by (ii) a methylation of the resulting intermediate $\left[\mathrm{ArSO}_{2} \mathrm{CH}\left(\mathrm{CO}_{2} \mathrm{Me}\right) \mathrm{R}(4)\right]$ yielding the methyl derivative $\left[\mathrm{ArSO}_{2} \mathrm{C}(\mathrm{Me})\left(\mathrm{CO}_{2} \mathrm{Me}\right) \mathrm{R}\right.$, (5); $B_{\mathrm{Al}} 2$ mechanism]. Finally, compound $\mathbf{5}$ undergoes a de-methoxycarbonylation reaction to the final product $\left[\mathrm{ArSO}_{2} \mathrm{CH}(\mathrm{Me}) \mathrm{R}\right]$.

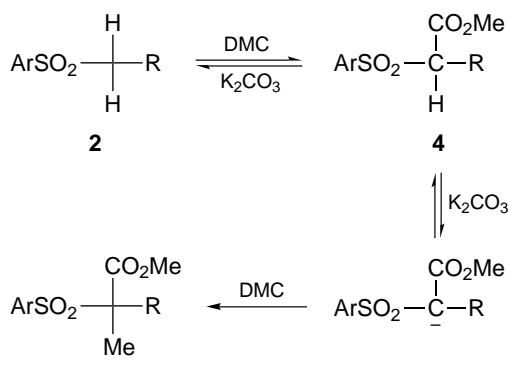

5

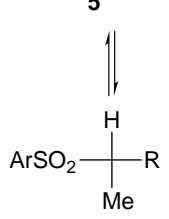

3

Scheme 1 Suggested mechanism for the mono-C-methylation of alkyl aryl sulfones with dimethyl carbonate

*To receive any correspondence (e-mail: selva@unive.it).

J. Chem. Research (S),
1997, 448-449

1997, 2688-2696 
Both intermediates $\mathbf{4}$ and $\mathbf{5}$ are detected during the reaction of DMC with sulfones $\mathbf{3 a}-\mathbf{h}$ (maximum amount of $10-30 \%$, by GC; structures assigned by GC-MS).

Also, methyl aryl sulfones $\left(\mathrm{ArSO}_{2} \mathrm{CH}_{3}\right)$ react with $\mathrm{DMC}$ as in Scheme 1: the formation of methoxycarbonylated compounds $\left(\mathrm{ArSO}_{2} \mathrm{CH}_{2} \mathrm{CO}_{2} \mathrm{Me}\right)$ as intermediates, allows the homologation of the methyl group to a isopropyl one. Thus, $\mathrm{PhSO}_{2} \mathrm{Me}$ yields $\mathrm{PhSO}_{2} \mathrm{CHMe}_{2}$ and $\mathrm{PhSO}_{2} \mathrm{C}\left(\mathrm{CO}_{2} \mathrm{Me}\right) \mathrm{Me}_{2}$ (6) $\left(12\right.$ and $81 \%$, respectively; $14 \mathrm{~h}$ at $180^{\circ} \mathrm{C}$; conversion 93\%). Likewise, $\mathrm{PhCH}_{2} \mathrm{SO}_{2} \mathrm{Me}$ affords $\mathrm{PhCH}(\mathrm{Me}) \mathrm{SO}_{2}$ $\mathrm{CHMe}_{2}$ and $\mathrm{PhCH}(\mathrm{Me}) \mathrm{SO}_{2} \mathrm{C}\left(\mathrm{CO}_{2} \mathrm{Me}\right)(\mathrm{Me})_{2}$ (7) (14 and $50 \%$, respectively; $21.5 \mathrm{~h}$ at $180{ }^{\circ} \mathrm{C}$; conversion $98 \%$ ). Compounds 6 and 7 have been isolated in 63 and 34\% yields, respectively (characterized by ${ }^{1} \mathrm{H}$ and ${ }^{13} \mathrm{C}$ NMR spectra).

${ }^{1} \mathrm{H}$ NMR and GC-MS spectra are given in the full text for all products.

The synthesis here discussed has both synthetic advantages and remarkable environmental benefits: $(i)$ it affords selectively only mono-methyl derivatives; (ii) it uses an intrinsically safe methylating agent (DMC) in place of the toxic methyl chloride (or dimethyl sulfate); (iii) it gives neither organic nor inorganic by-products (alkylation procedures using alkyl halides cannot avoid the formation of stoichiometric amounts of inorganic salts to be disposed of); (iv) it does not require additional solvents. Moreover, the procedure discloses intriguing perspectives of the chemistry of sulfonyl carbanions since it shows that these anionic moieties can actually be generated also in the presence of very mild bases.
Techniques used: ${ }^{1} \mathrm{H}$ and ${ }^{13} \mathrm{C}$ NMR, GC and GC-MS

References: 24

Table 1: Yields, reaction temperature and times, purification for products $\mathbf{3 a}-\mathbf{h}$

Received, 21st May 1997; Accepted, 1st September 1997

Paper E/7/03510A

\section{References cited in this synopsis}

1 P. D. Magnus, Tetrahedron, 1977, 33, 2019.

3 K. Kondo and D. Tunemoto, Tetrahedron Lett., 1975, 1007.

4 C. R. Hauser and T. M. Harris, J. Am. Chem. Soc., 1957, 79, 6342 .

5 E. M. Kaiser and C. R. Hauser, Tetrahedron Lett., 1967, 3341.

7 J. B. Hendrikson, A. Giga and J. Wareing, J. Am. Chem. Soc., 1974, 96, 2275.

12 F. Trotta, P. Tundo and G. Moraglio, J. Org. Chem., 1987, 52, 1300.

13 P. Tundo, F. Trotta and G. Moraglio, J. Chem. Soc., Perkin Trans. 1, 1989, 1070.

14 M. Selva, C. A. Marques and P. Tundo, J. Chem. Soc., Perkin Trans. 1, 1994, 1323.

15 P. Tundo and M. Selva, Chemtech, 1995, 25, 31.

16 A. Bomben, C. A. Marques, M. Selva and P. Tundo, Tetrahedron, 1995, 51, 11573.

18 M. Selva, A. Bomben and P. Tundo, J. Chem. Soc., Perkin Trans. 1, 1997, 1041. 